\title{
Review
}

\section{The Use of Nanoparticles for Gene Therapy in the Nervous System}

\author{
Francisco C. Pérez-Martínez ${ }^{\mathrm{c}}$, Blanca Carrión ${ }^{\mathrm{c}}$ and Valentín Ceña ${ }^{\mathrm{a}, \mathrm{b}, *}$ \\ ${ }^{a}$ Unidad Asociada Neurodeath, Departamento de Ciencias Médicas, CSIC-Universidad de Castilla-La Mancha, \\ Albacete, Spain \\ ${ }^{\mathrm{b}}$ CIBERNED, Instituto de Salud Carlos III, Albacete, Spain \\ ${ }^{\mathrm{c}}$ NanoDrugs, S.L. Parque Científico y Tecnológico, Albacete, Spain
}

Accepted 9 May 2012

\begin{abstract}
Nanoparticles represent an alternative to viral vectors for genetic material transfer to the nervous system. However, to increase transfection efficiency in the central nervous system and to decrease toxicity, the design of nanoparticles needs to be improved to enhance blood-brain barrier crossing and endosomal escape. This paper reviews the strategies used to solve these difficulties and covers the use of various nanoparticles including natural inorganic particles, natural polymers, cationic lipids, polyethylenimine derivatives, dendrimers, and carbon-based nanoparticles. The effectiveness, both in vivo and in vitro, of each method to deliver genetic material to neural tissue is discussed.
\end{abstract}

Keywords: Blood-brain barrier, dendrimers, gene transfer, nanoparticles, neurons, siRNA

Gene therapy can be described as the introduction of a functional gene into cells with a defective gene in order to treat diseases of genetic origin. However, a broader description would include the introduction of exogenous genetic material, either DNA, RNA interference (RNAi), or small interfering RNA (siRNA), to modify the signaling pathways of a given cell [1].

One of the main challenges to understanding the role of certain proteins in the mechanisms involved in neuronal physiology and pathology consists of selectively removing the target proteins to study their lack-offunction effects or, alternatively, over-express them to explore their function. For many years, the typical approach has consisted of generating knock-out mice who lack the target protein [2], but this is a time consuming method and, sometimes, the function of the

*Correspondence to: Prof. Valentín Ceña, Unidad Asociada Neurodeath, Facultad de Medicina, Avda. Almansa, 14, Albacete 02006, Spain. Tel.: +34 967599316; Fax: +34 967599316; E-mail: valentin.cena@gmail.com. removed protein can be replaced by another protein during development, a phenomenon known as redundancy that leads to a lack of phenotype, making it difficult to draw conclusions from the experiments performed in those animals. A more complex approach consists of generating conditional knock down or knock-in mice that only remove or express the protein following a specific treatment [3]. This procedure prevents compensation of function during development, but it is very time consuming and, technically, difficult to achieve. On the other hand, RNAi technology is considered to be a useful approach to study the role of various proteins in neuronal physiology because it is very specific and its acute effects preclude compensatory effects of other proteins for the function of the removed protein (Fig. 1). However, siRNA technology has scarcely been used in neurons due to the initial low efficiency of the non-viral vectors used to deliver siRNA to neural tissue. This has led to the use of viral vectors to transfer genetic material, specifically short hairpin RNA (shRNA) that has displayed the highest 


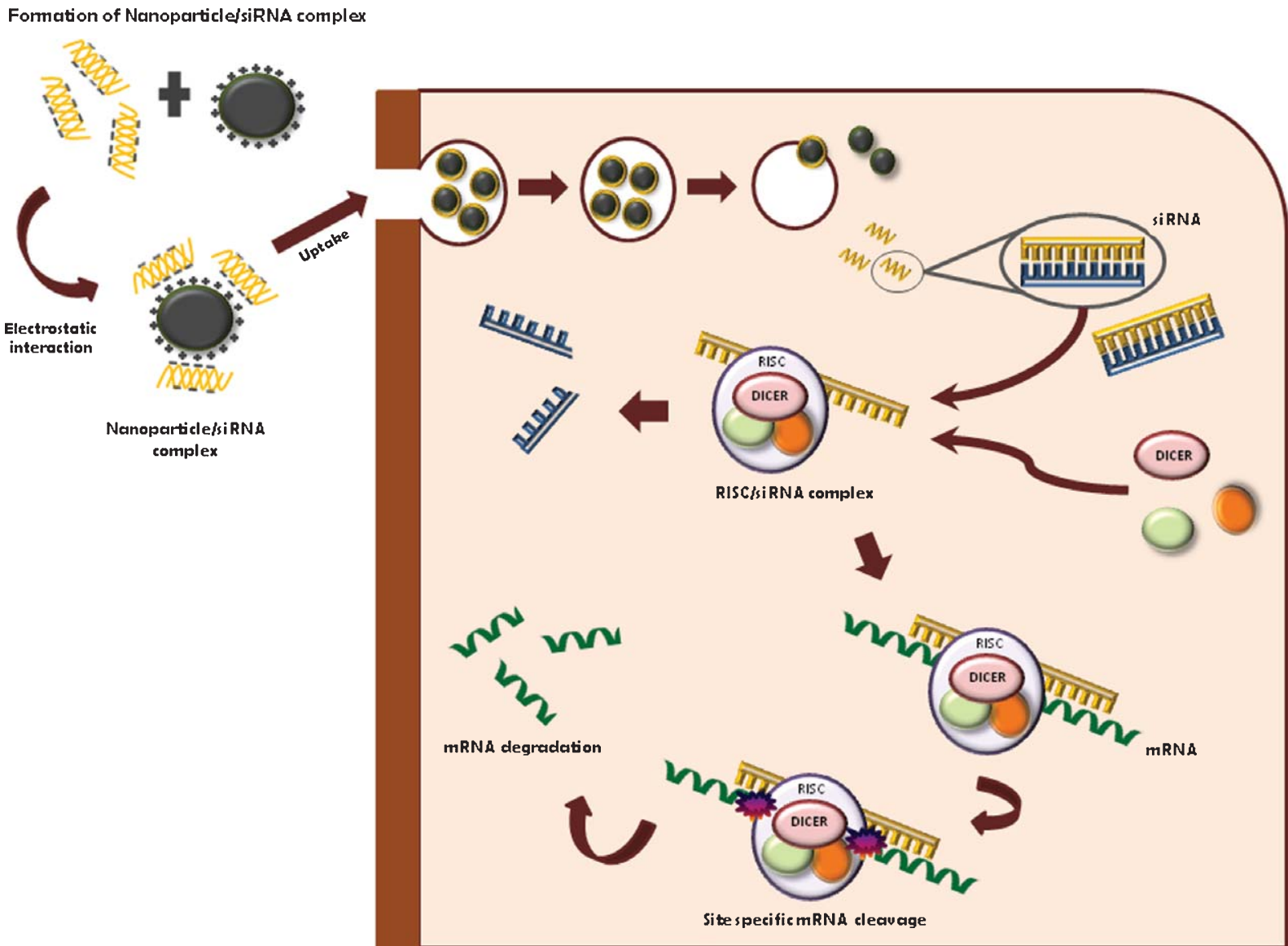

Fig. 1. Mechanism of action of siRNA. The nanoparticle complexed with siRNA is taken up by the cell through an endocytosis mechanism. The complex escapes from the endosome and the siRNA is released to the cytosol. Once released, the siRNA is incorporated into the RISC complex where it interacts with its target mRNA causing the cleavage of the later.

transfer efficiency to introduce siRNA into neural cells achieving around $80 \%$ inhibition of specific protein levels [4]. However, the use of viral vectors has different drawbacks such as: a) technical difficulties in producing the vectors; $b$ ) the high cost of production; $c$ ) the production of neutralizing antibodies which limits their effectiveness either by a humoral response following repeated administrations of the viral vector [5] or by the presence of a prior infection like in the case of the use of adeno-associated virus [6]; and d) safety concerns like the occurrence of insertional mutagenesis during human gene therapy trials [7]. These drawbacks represent a barrier to the use of viral vectors and were aggravated by the death of patients participating in clinical trials using these vectors [8-10]. This has posed a serious limitation to the use of this strategy for human use leading to the research on nanoparticles (NPs) as an alternative method for delivering RNAi to mammalian cells.
NPs are very diverse chemical structures that share specific properties due to their nanometric size (one $\mathrm{nm}$ to one $\mu \mathrm{m})$. A common feature of all nanomaterials is their large ratio of surface area to volume, which may be orders of magnitude greater than that of macroscopic materials. Their properties include interaction with many biological molecules including proteins and nucleic acids. Therefore, the use of NPs has been proposed to overcome the problems generated by the use of viral vectors. Initially, NPs demonstrated lower transfection efficiency than viral vectors in the nervous system [11]. However, new chemical functionalizations have markedly improved the efficacy of NPs in transfecting genetic material to neuronal cells. Recently, useful reviews of the use of various NPs to transfect genetic material have been published [12-15].

This review focuses on the use of various types of NPs such as inorganic NPs, natural polymers, 
A

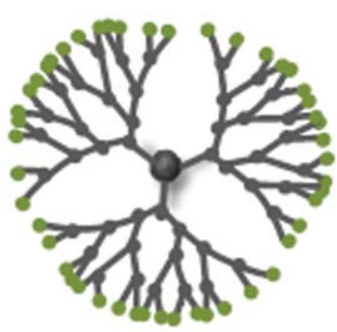

Dendrimer

D

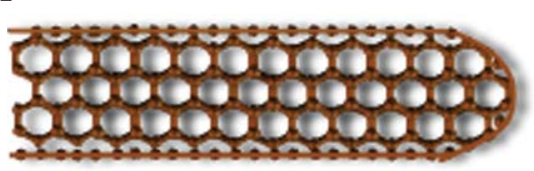

Carbon-based Nanoparticle

\section{Types of nanoparticles}

B

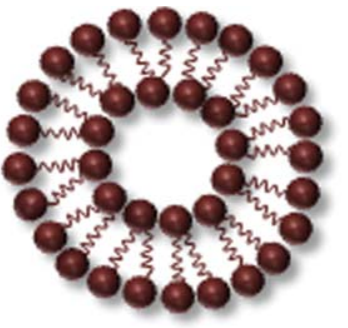

Lipid-based Nanoparticle

E

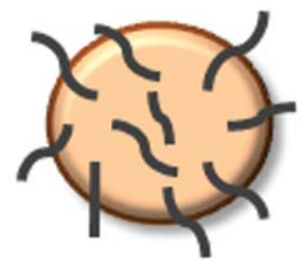

Inorganic Nanoparticle
C

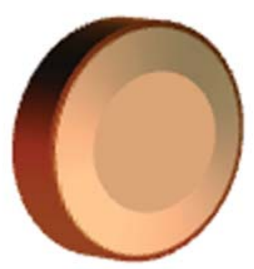

Polymeric Nanoparticle

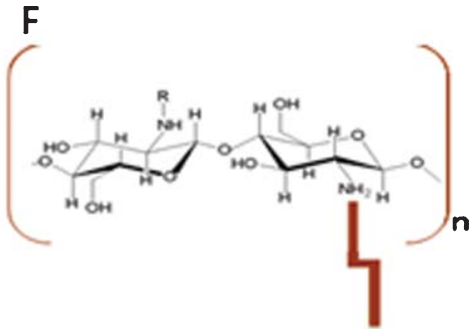

Natural Polymer

Fig. 2. Scheme showing the different types of nanoparticles covered in this review. The size of each individual nanoparticle varies but it is smaller than $100 \mathrm{~nm}$.

cationic lipids, polyethylenimine (PEI) derivatives, dendrimers, and carbon-based NPs (Fig. 2) as genetic material delivery agents and their toxicity in the nervous system.

\section{GENERAL ASPECTS OF BIOLOGICAL BARRIERS CROSSING BY NANOPARTICLES}

To achieve its function as a gene delivery carrier for the central nervous system (CNS), delivery agents in general and NPs in particular must: a) cross one or several membrane layers (e.g., mucosa, epithelium, endothelium); b) be internalized into the CNS by crossing the blood-brain barrier (BBB) or by travelling through nerve terminals; c) diffuse through the neuronal or glial cytoplasmic membrane; d) escape from encapsulation in organelles; and e) release their genetic material cargo. These two later actions are specific for NPs since viruses are not generally encapsulated in intracellular organelles and do no release their genetic cargo but rather synthesize it. In addition, premature degradation of the NP and its cargo before it reaches its intracellular target must be prevented (Fig. 3).

There are two important aspects to be considered in order to achieve effective NP delivery of genetic material to CNS cells: BBB crossing and endosomal escape.

\section{$B B B$ crossing}

$\mathrm{BBB}$ crossing is perhaps the main bottleneck for the transfection of neurons in vivo. This section will focus on a short description of the $\mathrm{BBB}$, since recent reviews have specifically covered this subject [16]. The BBB is a physical barrier that limits brain uptake of therapeutic drugs (Fig. 4). Neurotropic viruses like those used as delivery vectors for genetic material gain access to the CNS either by using the neuronal network and the axonal transport or by invading the CNS from the bloodstream. On the other hand, the main process used by nanocarriers to cross the BBB is called transcytosis (direct penetration) [17], which is partly prevented by the activity of efflux pumps such as p-glycoprotein [18].

However, NPs may also cross this barrier by simple diffusion (adsorptive transcytosis) or by receptormediated endocytosis. In the case of simple diffusion, only small compounds and highly hydrophobic compounds smaller than $600 \mathrm{Da}$ can cross the BBB. Endothelial cells of the BBB are characterized by a lack of fenestrations, diminished pinocytic activity, and the presence of tight junctions, that together result in 


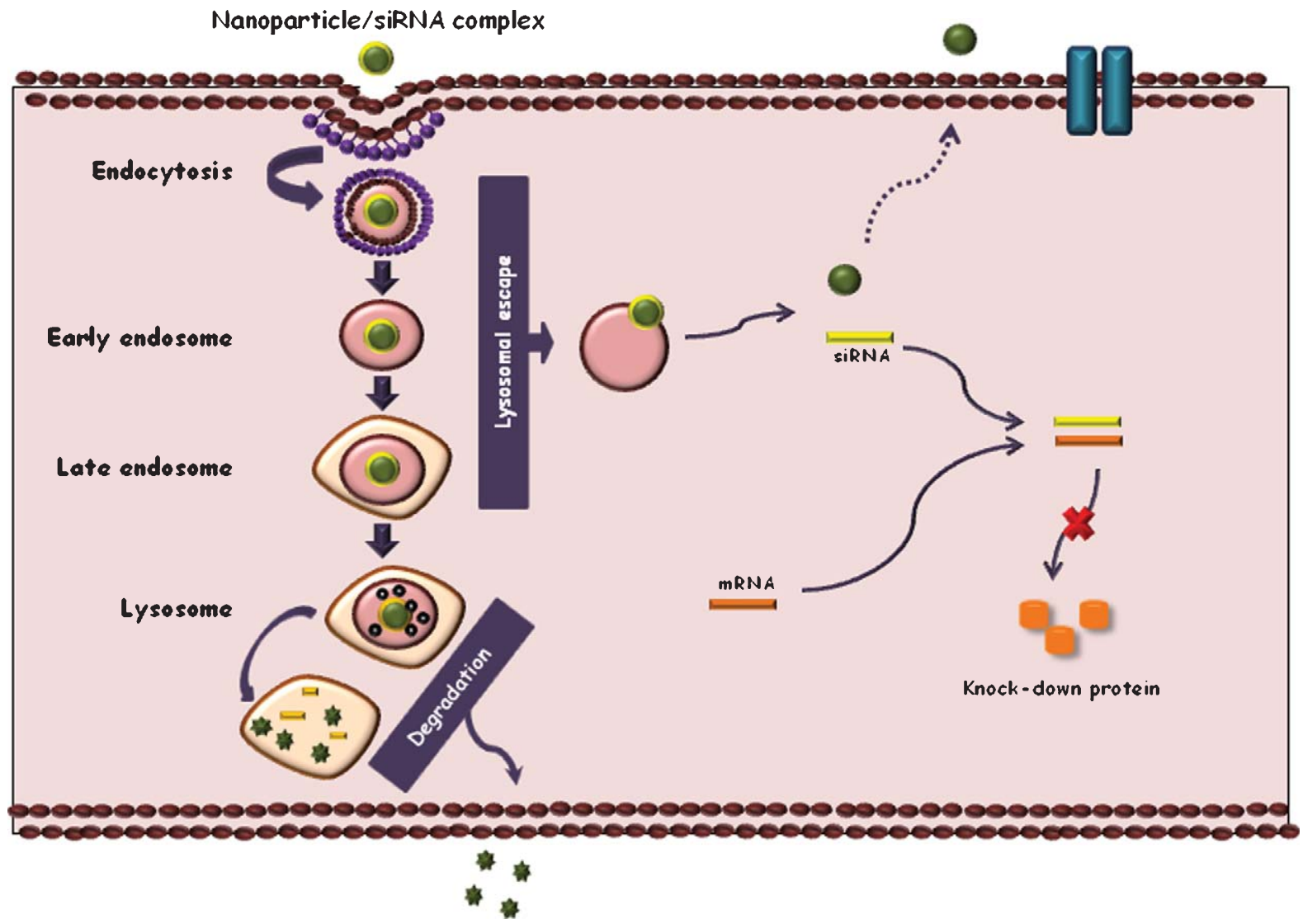

Fig. 3. Intracellular fate of the nanoparticle/siRNA complex. Once taken up by the endosomes, the nanoparticle can either escape from the lysomes releasing it in the cytosol or be degraded, together with its cargo, by the lysosomes.

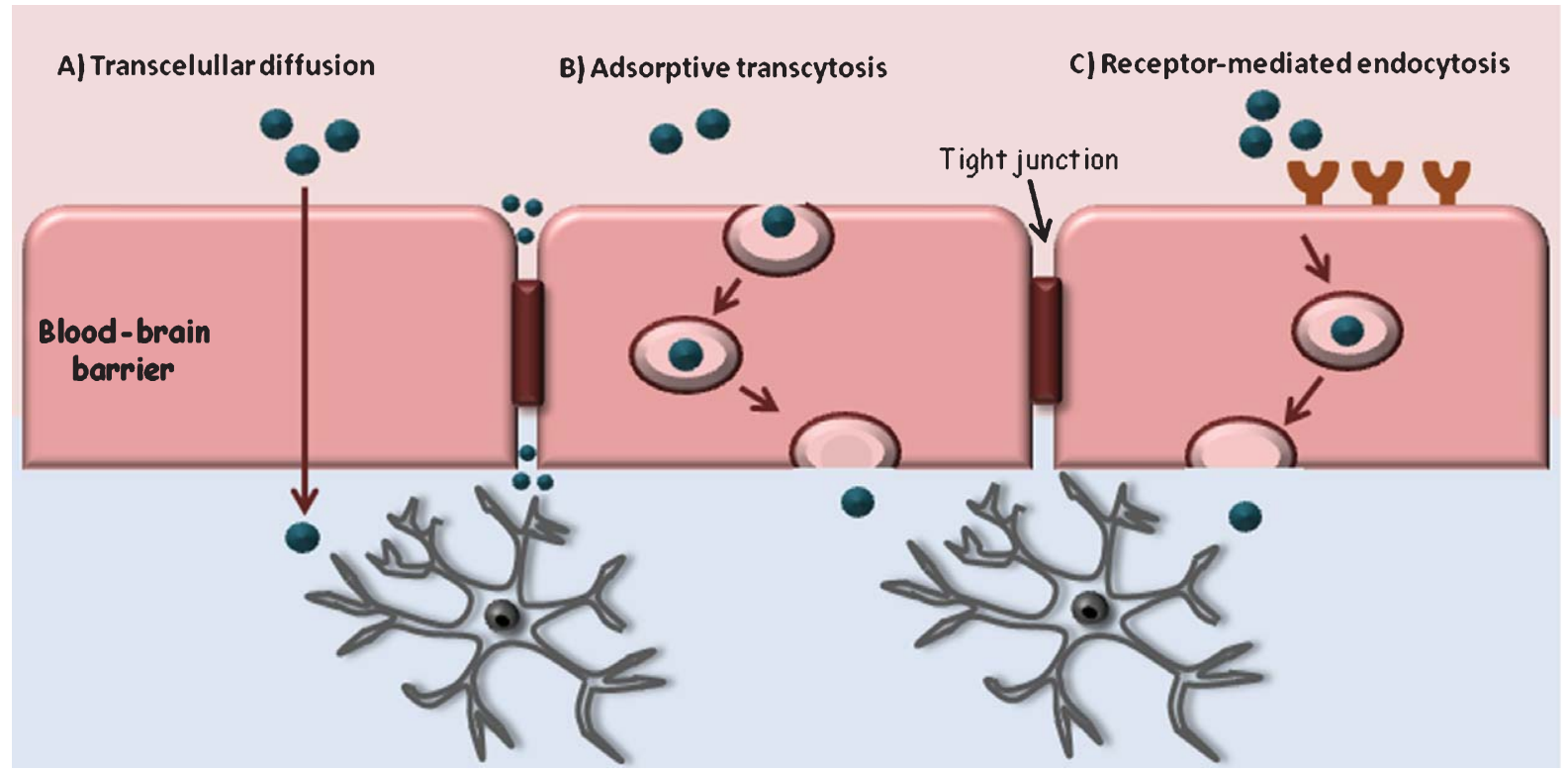

Fig. 4. Blood-brain barrier crossing mechanisms used by nanoparticles. 
very low paracellular permeability, blocking access of NPs to the CNS $[19,20]$. However, several NPs can transiently and reversibly open the tight junctions thus increasing the paracellular permeability of the endothelial cells and the perycites, the specialized cells that surround the brain capillaries [21]. Nevertheless, tight junctions can be opened up to $20 \mathrm{~nm}$ wide [22], and thus, only NPs smaller than this size may use this pathway to penetrate into the brain through the $\mathrm{BBB}$. It is important to note that several CNS diseases (infection or multiple sclerosis) as well as some solid tumors (glioblastomas) may also lead to some loss of BBB integrity, thus facilitating NPs entry into the brain parenchyma.

A useful approach to increase BBB crossing by NPs has consisted in coupling to them different ligands like poly(ethylene glycol) (PEG), lactoferrin (Lf) [23], the peptide angiopep-2 [24], transferrin (Tf) [25], and thiamine [26], suggesting that these molecules play a critical role in the endocytosis of these NPs by the brain vascular endothelial cells [27-29]. The conjugation of different NPs to specific ligands to facilitate $\mathrm{BBB}$ crossing represents a clear advantage of NPs over the viral vectors that cannot be coupled to targeting molecules. So it has been shown that NPs conjugated with $\mathrm{Tf}$ increased the penetration through the BBB and the delivery of different molecules to the brain [30]. Moreover, D-glucosamine-modified NPs were able to deliver a significant amount of methotrexate to the CNS following intravenous administration [31]. Similar results on BBB crossing have been reported for Lf [23] and angiopep-2 [24] modified NPs. Additional strategies to increase BBB crossing and delivery to neurons have been developed including coupling of the NPs to a peptide derived from the rabies virus [32] and what is known as a "Trojan horse" effect where modified NPs were used to internalize an antiretroviral drug (indinavir) into bone-marrowderived macrophages allowing these indinavir-loaded macrophages to reach easily the brain and release there the active drug [33].

\section{Endosomal escape}

The other major limiting step in the use of NPs in the CNS is endosomal escape [34], a common barrier for the transfection of practically every cell type. Thus, differences in intracellular trafficking can occur mainly based on the different uptake mechanisms used by the NPs [35], although NPs may also enter into cells via a common entry mechanism and subsequently be sorted into various cellular routes after internalization [36].
Therefore, NPs, as other molecules, internalized by endocytosis are generally enclosed in vesicles from which they must escape, to find the target sites for their cargo, before they enter the lysosomes where the low $\mathrm{pH}$ and the high concentration of degrading enzymes can inactivate the NPs and their cargo. In this regard, positively charged NPs such as PEI and dendrimers are more efficient transfection agents, as they are able to escape from endosomes in neurons [37-39].

One of the proposed mechanisms for endosomal escape is the "proton sponge" hypothesis, which indicates that the endosomal $\mathrm{pH}$ decreases due to the positive charges of the NPs, resulting in water entry and osmotic swelling, leading to vacuole disruption and the cytoplasmic release of the NP and its cargo [37]. This would suggest that positively charged NPs have an advantage as transfection agents over other types of NPs [40]. However, the "proton-sponge" effect cannot explain the endosomal/lysosomal escape for all types of NPs. Those NPs taken up by a caveolae-mediated mechanism (CvME) avoid the lysosomes. To take advantage of this property, NPs are coupled to ligands known to be internalized by this pathway. Therefore, modification of the surface of NPs with the TAT protein or LDL has been used to increase the uptake of NPs by several cells $[41,42]$ through mechanisms involving macropinocytosis, clathrin-mediated endocytosis (CME), and CvME [43]. In addition, NPs coated with the cationic lipid stearylamine showed increased and faster uptake by cells using the CME pathway [44]. On the other hand, drugs and genetic material must be released quickly from the delivery system, since endocytic internalization is a fast process. To achieve this release, several approaches have been used including $\mathrm{pH}$ sensitive bonds which are stable at physiological $\mathrm{pH}$, but upon acidification in the endosomes they are hydrolized, destabilizing the molecule and releasing the associated cargo [45]. In addition, ligands such as DOPE (dioleoylphosphatidylethanolamine) and thiol groups have been shown to promote leakage of the NPs from the endosomes [46] increasing transfection efficiency.

\section{NANOPARTICLES USED FOR CNS DELIVERY OF GENETIC MATERIAL}

In the $1980 \mathrm{~s}$, a number of new techniques were devised to introduce foreign DNA into eukaryotic cells. Initially, the most commonly used techniques were DNA/calcium phosphate co-precipitation or methods based on the use of lipids or high molecular weight 
polycations such as dextran. However these methods showed high variability depending on cell type and high toxicity in primary cultures. The maximum transfection efficiency obtained in mice hypothalamic neurons using these methods ranged from $3.5 \%$ to $6.5 \%$ for electroporation followed by DEAE-Dextran treatment.

\section{Inorganic nanoparticles}

Inorganic NPs are nanostructures of varying size and shape and porosity, which can be engineered to evade the reticuloendothelial system or to protect an entrapped molecular payload from degradation or denaturation [47]. They include silica and calcium phosphate as well as several magnetic compounds [48-50].

Silica-coated NPs are biocompatible structures that have been used for various biological applications including artificial implants [51] and for drug delivery because of their defined structures, high stability, surface properties, and biocompatibility [52, 53]. Furthermore, silica has been used to improve the biocompatibility (which is a general problem for all nanomaterials interacting with biological tissues) of other types of NPs used as non-viral delivery systems [54]. Several studies have examined the viability of this type of NP as a gene delivery system in various CNS cell types, although only limited efficiency has been achieved [55], suggesting that this kind of NP should be modified to be more useful for genetic material delivery to the nervous system. More recently, it has been reported that mesoporous silica NPs loaded with a second generation poly(amidoamine) (G2-PAMAM) dendrimer show gene transfection efficiency in vitro in glial cells [56]. Besides classic inorganic NPs, new biocompatible magnetic NPs have the potential to be used to deliver genetic material to neural cells because, following endovenous administration, they can reach the CNS without apparent toxicity $[57,58]$ and have shown effectiveness in vitro [59].

\section{Natural polymers}

The more widely used natural polymers are chitosan and collagen. Chitosans are naturally derived cationic polysaccharides that are highly attractive as drug and gene delivery candidates [60] mainly due to their biodegradability and safety. However, the transfection efficiency obtained using these polymers is very low [61]. Collagen is another important natural polymer that has been used for DNA delivery. Using a complex of pDNA and atelocollagen (a modified form of collagen) is possible, but even when an implanted pellet prolonged the residence time of applied pDNA [62], the effectiveness for DNA transfection was low.

\section{Cationic lipid-based nanoparticles}

Cationic lipid-based vectors include liposomes, micelles and solid lipid NPs (SLNs), with liposomes the most commonly used. Their structure involves a cationic head group, a linker, and a hydrophobic part, which allow them to generate spherical structures with an aqueous core and a diameter of about $200 \mathrm{~nm}$ [63]. This type of NP has been widely used to transfect nucleic acids into mitotic cells [64], although when used in neurons, transfection efficiency is low [38, 65]. Liposomes are lipidic vesicles, formed by one or several phospholipids bilayers surrounding an aqueous core. The amphiphilic nature of liposomes, their ease of surface modification, and their good biocompatibility profile make them an appealing solution for increasing the circulating half-life of the generally hydrophilic cargo molecules. The molecules remain encapsulated in the aqueous interior, or in hydrophobic compounds, which may escape encapsulation through diffusion out of the phospholipid membrane [66, 67]. This kind of cationic lipid-based NP has not made a significant medical impact yet, although they have been extensively employed in cosmetic products [67]. Presumably, the lack of widespread medical impact is due to their limited biological stability. Moreover, the mean size of the liposomes (about $200 \mathrm{~nm}$ ) may also limit their ability to breach the BBB and to be internalized by most of the endocytotic pathways, although these issues have been avoided by using liposomes modified with Tf, antibody fragments to the Tf receptor, PEG, and TAT peptides [68-71]. Some studies have shown that certain genes can be delivered into the brain using liposomes. The first in vivo study appeared in 1990 and showed that direct administration of liposome-DNA complexes into the brain of vertebrates lead to successful transfection of neurons [72]. Later, direct brain injection of a liposomal complex carrying a plasmid encoding tyrosine hydroxylase (TH), in an experimental model of Parkinson's disease in rats, resulted in improvement in the animals [73, 74]. Similar studies transfected a gene encoding neurotrophic growth factor, using cationic liposomes modified with several molecules such as cholesterol and $\mathrm{Tf}$, with relatively good results in alleviating neuronal injury [75, 76]. Several attempts have been made to improve liposomemediated gene delivery to the brain including coupling 
Tf [70] or monoclonal antibodies (immunoliposomes) directed against either the Tf receptor or the insulin receptor. The latter were effective in carrying a plasmid DNA encoding an EGFR antisense after parenteral administration in mice bearing U87 xenografted brain tumors [77]. These results were confirmed in other studies in which immunoliposomes carrying a short hairpin RNA targeting EGFR mRNA were used in a brain glioma model [78, 79].

Solid lipid NPs are considered safe and useful materials for non-viral delivery systems [80] and have been also used as brain delivery systems in CNS cells in vitro and in vivo [81-83]. However, some of these NPs need to be stabilized, using molecules such us lecithins, polysorbates, poloxamers, derivatized fatty acids, and their combinations in order to be useful as brain delivery systems $[84,85]$. After modification, solid lipid microemulsions loaded with iron oxide systemically injected in rats can cross the BBB and accumulate in the brain [86]. In addition, other SLNs modified with biocompatible materials have shown significant brain uptake and have been proposed for gene delivery to the brain $[26,87]$.

\section{Polyethylenimine-derived nanoparticles}

The most widely used polymeric NP used for gene delivery is PEI [88], although other biodegradable polymers such as poly(butyl cyanoacryalate) have been used as non-viral vectors in the brain $[89,90]$. In addition, there are other polyesters officially approved for clinical use such as copoly lactic acid/glycolic acid and poly lactic acid, which have low toxicity and are potentially useful for gene delivery to the brain [91, 92].

PEI is produced by the polymerization of aziridine and has been used to transfect genetic material into various cell types both in vitro and in vivo [37, 88]. The polymer exists in two forms: the linear form and the branched form, and the branched structure is more efficient in condensing nucleic acids than linear PEIs [93]. These NPs are protonated as result of the decrease in endosomal $\mathrm{pH}$, leading to disruption of the vacuoles and the subsequent release of the NPs and their cargo $[37,94]$. This ability to escape from the endosomes as well as the ability to form stable complexes with genetic material provides the foundation for its use as a gene delivery vector [37]. However, its use is still hampered by relatively low transfection efficiency, short duration of gene expression, and elevated toxicity when compared to viral transfection vehicles $[95,96]$. In neurons, the first studies obtained with these NPs showed a transfection efficiency of about $9-15 \%$ [95,
96]. This transfection efficiency can be increased if PEI NPs are modified with hydrophobic molecules, such as cholesterol, to form water-soluble lipopolymers, which can be taken up by neurons through receptor-mediated endocytosis [97]. In addition, other molecules including the nerve growth factor loop 4 hairpin structure, Tf, botulinum toxin, or tetanus toxin have been successfully added to PEI-based NPs to form polyplexes showing higher transfection efficiency in CNS cells [98-101]. Covalent modifications of the PEI surface with PEG derivatives have been also used to reduce NP liver uptake and to increase their persistence in peripheral circulation [102-104]. On the other hand, surfactants have been incorporated into NPs to increase PEI blood levels as well as their accumulation in other organs such as the brain [105, 106]. PEI-based vectors have been used to deliver oligonucleotides [107], plasmid DNA [108] and RNA, and intact ribozymes [109] to non-neural cells with varying efficiency depending on the structure of the NP.

PEI-based NPs have shown efficiency in in vivo gene delivery in the brain, producing transgene expression in cortical neurons [88]. These effects have been confirmed in studies in which intraventricular injection of PEI-DNA complexes resulted in diffusion of the complexes from the injection site to the entire brain ventricular space, transfecting neurons in several brain areas [110]. On the other hand, the injection of PEI/DNA complexes into cerebrospinal fluid or into the lateral ventricle produces a distribution of gene expression within both sides of the brain [110, 111]. Other administration routes such as the lumbar subarachnoid space have also provided enhanced transgene expression in the spinal cord [112, 113]. However, the main drawback of this type of NP is that it requires in situ injection in the brain to be effective. Limited transfection can be obtained taking advantage of the ability of PEI-based NPs alone or in complex with other type of NPs that display trans-synaptic retrograde transport along neurites. These NPs travel from peripheral nerve terminals to neuronal cell bodies in the CNS (as occurs with the transport of some pathogens and toxins), where they can deliver therapeutic agents [114]. Moreover, PEI/DNA complexes have been injected into the tongue, achieving retrograde axonal transport to hypoglossal motoneurons of the brain stem [115].

\section{Dendrimers}

Dendrimers are polymer-based molecules with a symmetrical structure in precise sizes and shapes as 
well as terminal group functionality. They have been used for numerous applications including gene delivery, catalysis, and electronics [116]. These NPs contain three distinct regions: a) central core (a single atom or a group of atoms having two or more identical chemical functionalities); b) branches emanating from the core, which are composed of repeat units with at least one branching junction whose repetition is organized in a geometric progression that results in a series of radially concentric layers; and c) terminal functional groups. These groups are located on the exterior of the macromolecule and facilitate interactions with solvents, surfaces, or other molecules. Increased growth is defined in terms of 'generation number', with each generation of dendrimer characterized in terms of size, shape, molecular weight, and number of surface functional groups.

Dendrimers bind to nucleic acids, when peripheral groups that are positively-charged at physiological $\mathrm{pH}$ interact with the negatively-charged phosphate groups of the nucleic acids [117]. Dendrimers have a good toxicity profile, although toxicity increases as a function of the number of terminal amino groups and positive charge density, in other words, as a function of generation number. Although they share a general chemical structure (central core and branches), dendrimers differ markedly in their chemical structure, which leads to differences in their ability to cross biological barriers and their effectiveness as genetic material delivery agents to the nervous system. Dendrimers can also be useful to either facilitate or prevent genetic material delivery to the cell nucleus. Thus fourth generation (G4) polyamidoamine (PAMAM) dendrimers have been coupled to dexamethasone to facilitate nuclear transport of the corticoid/dendrimer complex [118]. On the other hand, $17 \beta$ estradiol was coupled to a sixth generation (G6) PAMAM dendrimer that, due to its size, cannot enter the nucleus, to study the extranuclear actions of the estrogen on intracellular calcium oscillations in primate luteinizing hormone releasing hormone-1 neurons [119]. Another interesting application of dendrimers is their use as biosensors. In this field, a G4-PAMAM dendrimer containing encapsulated $\mathrm{Au}$ has been used to detect $\alpha$-synuclein [120].

However, the most interesting application of dendrimers is as gene delivery vectors. In vitro, various dendrimers have shown the ability to efficiently deliver siRNA to cultured neuronal cells. A carbosilane dendrimer was used to deliver siRNA to cultured rat cortical neurons. At $18 \mathrm{~h}$ post-transfection, approximately $85 \%$ of the neurons contained fluoresceinlabeled siRNA/dendrimer complex. Analysis of the target protein (hypoxia-inducible factor- $1 \alpha$ ) showed a reduction of about $80 \%$ of the total protein content with no toxic effects on the neurons [121]. Furthermore, to increase NP entry into neurons, dendrimers have been covalently linked to rabies virus glycoprotein peptide (RVG29) [32] and they have been modified with arginine [122]. In this regard, an arginine-modified PAMAM dendrimer has been reported to produce siRNA delivery and transfection levels of $35-40 \%$ in primary cortical neurons, levels significantly higher than that obtained with other NP types such as cationic lipid-based NPs and PEIbased NPs [122]. More recently, another study reported that PAMAM dendrimers modified with arginine allow siRNA delivery to a primary culture of mixed cortical cells containing neurons and glia, thereby resulting in a reduction of about $80 \%$ in High Mobility Group Box 1 (HMGB1) protein levels $12 \mathrm{~h}$ post-transfection [123]. A new hybrid dendrimer (TRANSGEDEN) that combines a conjugated rigid polyphenylenevinylene (PPV) core with flexible PAMAM branches at the surface can deliver specific siRNA to decrease cofilin1 levels in rat cerebellar granular neurons to about $20 \%$ of control values without apparent signs of toxicity [124]. Moreover, this dendrimer has been used to deliver siRNA to cortical neurons and efficiently knock down cofilin-1 and the phosphatase Slingshot $1 \mathrm{~L}$ (SSH-1 L), unveiling a key role for cofilin in excitotoxic death, which requires activation by SSH-1 L, but not by chronophin phosphatase [125]. In addition, beclin-1 knock down using a specific siRNA delivered by the TRANSGEDEN dendrimer, potentiated NMDA-induced neuronal death, indicating that autophagy plays a protective role during excitotoxicity and suggesting that targeting autophagy might be a helpful therapeutic strategy in neurodegenerative disorders [39]. Finally, in a different approach, dendrimer-conjugated elongated magnetofluorescent particles (nanoworms) have been used to deliver siRNA in vitro. Using this approach, it has been shown that these dendrimers carrying siRNA against the epidermal growth factor receptor (EGFR) reduced protein levels in human glioblastoma cells by 70 to $80 \%$, which is 2.5-fold more efficiently than commercial cationic lipid-based NPs [126]. However, they required intracerebral application to be partially efficient in vivo.

Dendrimers have been also modified for their use in vivo as delivery agents using some of the modifications described above for facilitating BBB crossing. Some of them include coupling to specific ligands such as thiamine or Tf $[25,71,127]$. Also, PAMAM dendrimers have been modified with Angiopep-2, Tf, 
or lactoferrin to efficiently deliver genetic material to brain tissue in vivo after intravenous administration [24, 128, 129]. Another approach consists of using intranasal delivery of a PAMMAM degradable dendrimer coupled to siRNA to decrease HMGB1 expression in the brain, leading to a decrease in infarct volume in a model of middle cerebral artery occlusion [130].

\section{Carbon-based nanoparticles}

Carbon nanotubes (CNTs) are cylindrical nanostructures, composed of one (single-walled CNTs) or several (multi-walled CNTs) graphene sheets rolled concentrically and closed at each end by hemispherical fullerene caps (Figure 2). They have a radius of a few nanometers and are characterized by a high aspect ratio and variable length, usually below $1 \mu \mathrm{m}$. CNTs have various uses in neuroscience, including their potential in the development of a variety of miniaturized devices [131], the generation of neural interfaces [132], and novel molecular sensing [133], as well as genetic material delivery [134]. Furthermore, biocompatible platforms to support their growth in cultured cortical neurons have been prepared using CNTs [135-137]. CNTs have large internal volumes and the external surface can easily be functionalized. While they are promising for pharmaceutical applications, human tolerance of these compounds remains unknown, because they have two main disadvantages: a lack of solubility and potential toxicity due primarily to their needle-like shape and biopersistence, since they cannot be metabolized due to their graphitic nature [138]. Extensive research into the biocompatibility and toxicity of CNTs is ongoing.

Carbon nanohorns represent a new class of carbonbased NPs. They were discovered in 1999 by Iijima et al. [139]. They belong to the fullerene family and have large surface areas, a diameter of 2-3 nm and an average length of $30-50 \mathrm{~nm}$, and can be prepared with high purity. Due to strong van der Waals forces, they form unique nanoscale spherical dahlialike assemblies with a large number of horn-shaped, short, single-layered nanotubes that protrude in all directions. These structures show high adsorbability for therapeutic drugs, genes, or proteins due to their large surface area and large number of cavities. However, their efficiency as synthetic vehicles for intracellular delivery is limited because of their insolubility in water and their strong tendency to agglomerate into micron size structures [140, 141].

\section{CONCLUSIONS}

Nanomedicine and NPs will form the foundation for the therapeutic administration of genetic material to the nervous system, which is one of the frontiers of modern medicine. However, before success can be achieved, NP development must overcome several challenges including: a) better biocompatibility; b) BBB crossing; c) selective cellular delivery; and d) increased efficiency by improving endosomal escape. Among these difficulties, BBB crossing is currently the most important to overcome, to boost of the use of NPs to study the physiology, or to treat pathologies of the CNS. Currently, the addition of BBB-permeating peptides seems to be the most promising approach, but caution should be maintained because of possible modification of the biodistribution of the original NP after attachment of peptides. However, the most challenging task in terms of NP design will be the selective targeting of NPs and their cargo to specific cell types. This task is highly complex in the CNS due to the lack of knowledge of the differential characteristics between neuronal types, which may be useful for specific delivery of the NPs and their cargo.

The proper design of NPs to overcome these problems will lead to generalized use of RNAi technology. This technology can selectively inhibit the expression of proteins involved in signaling pathways activated during the development of CNS diseases, proteins that cannot easily be inhibited by traditional drugs. Current data strongly support the idea that dendrimers are the most promising NPs to achieve this goal.

\section{ACKNOWLEDGMENTS}

F.C.P-M. and B.C. are recipients of Torres Quevedo contracts from Ministerio de Ciencia e Innovación (Spain) and NanoDrugs, S.L. This work has been supported, in part, by grants PI081434 from Fondo de Investigaciones Sanitarias, BFU2011-30161-C02-01 from Ministerio de Ciencia e Innovación; PII1I090163-4002 and POII10-0274-3182 from Consejería de Educación, JCCM to V.C.

Authors' disclosures available online (http://www.jalz.com/disclosures/view.php?id=1323).

\section{REFERENCES}

[1] Posadas I, Guerra FJ, Ceña V (2010) Nonviral vectors for the delivery of small interfering RNAs to the CNS. Nanomedicine (Lond) 5, 1219-1236.

[2] Morrison RS, Wenzel HJ, Kinoshita Y, Robbins CA, Donehower LA, Schwartzkroin PA (1996) Loss of the p53 tumor 
suppressor gene protects neurons from kainate-induced cell death. J Neurosci 16, 1337-1345.

[3] Christophorou MA, Martin-Zanca D, Soucek L, Lawlor ER, Brown-Swigart L, Verschuren EW, Evan GI (2005) Temporal dissection of 533 function in vitro and in vivo. Nat Genet 37, 718-726.

[4] Fernandez M, Segura MF, Sole C, Colino A, Comella JX, Ceña V (2007) Lifeguard/neuronal membrane protein 35 regulates Fas ligand-mediated apoptosis in neurons via microdomain recruitment. J Neurochem 103, 190-203.

[5] Xiao X, Li J, Samulski RJ (1996) Efficient long-term gene transfer into muscle tissue of immunocompetent mice by adeno-associated virus vector. $J$ Virol 70, 8098-8108.

[6] Chirmule N, Xiao W, Truneh A, Schnell MA, Hughes JV, Zoltick P, Wilson JM (2000) Humoral immunity to adenoassociated virus type 2 vectors following administration to murine and nonhuman primate muscle. $J$ Virol 74, 24202425.

[7] Olsen NJ, Stein CM (2004) New drugs for rheumatoid arthritis. N Engl J Med 350, 2167-2179.

[8] Hollon T (2000) Researchers and regulators reflect on first gene therapy death. Nat Med 6, 6-10.

[9] Verma IM (2000) A tumultuous year for gene therapy. Mol Ther 2, 415-416.

[10] Check E (2005) Gene therapy put on hold as third child develops cancer. Nature 433, 561-564.

[11] Kulkarni M, Greiser U, O’Brien T, Pandit A (2010) Liposomal gene delivery mediated by tissue-engineered scaffolds. Trends Biotechnol 28, 28-36.

[12] Breunig M, Bauer S, Goepferich A (2008) Polymers and nanoparticles: Intelligent tools for intracellular targeting? Eur J Pharm Biopharm 68, 112-128.

[13] Itaka K, Kataoka K (2009) Recent development of nonviral gene delivery systems with virus-like structures and mechanisms. Eur J Pharm Biopharm 71, 475-483.

[14] Medina SH, El-Sayed ME (2009) Dendrimers as carriers for delivery of chemotherapeutic agents. Chem Rev 109, 31413157.

[15] Pérez-Martínez FC, Guerra J, Posadas I, Ceña V (2011) Barriers to non-viral vector-mediated gene delivery in the nervous system. Pharm Res 28, 1843-1858.

[16] Yang H (2010) Nanoparticle-mediated brain-specific drug delivery, imaging, and diagnosis. Pharm Res 27, 1759-1771.

[17] Faraji AH, Wipf P (2009) Nanoparticles in cellular drug delivery. Bioorg Med Chem 17, 2950-2962.

[18] Misra A, Ganesh S, Shahiwala A, Shah SP (2003) Drug delivery to the central nervous system: A review. $J$ Pharm Pharm Sci 6, 252-273.

[19] Crone C, Christensen O (1981) Electrical resistance of a capillary endothelium. J Gen Physiol 77, 349-371.

[20] Rubin LL, Staddon JM (1999) The cell biology of the bloodbrain barrier. Anпи Rev Neurosci 22, 11-28.

[21] Kotze AF, Luessen HL, de Leeuw BJ, de Boer AG, Verhoef JC, Junginger HE (1998) Comparison of the effect of different chitosan salts and $\mathrm{N}$-trimethyl chitosan chloride on the permeability of intestinal epithelial cells (Caco-2). J Control Release 51, 35-46.

[22] Adamson RH, Lenz JF, Zhang X, Adamson GN, Weinbaum S, Curry FE (2004) Oncotic pressures opposing filtration across non-fenestrated rat microvessels. J Physiol 557, 889907.

[23] Huang R, Ke W, Han L, Liu Y, Shao K, Jiang C, Pei Y (2010) Lactoferrin-modified nanoparticles could mediate efficient gene delivery to the brain in vivo. Brain Res Bull 81, 600604.
[24] Ke W, Shao K, Huang R, Han L, Liu Y, Li J, Kuang Y, Ye L, Lou J, Jiang C (2009) Gene delivery targeted to the brain using an Angiopep-conjugated polyethyleneglycolmodified polyamidoamine dendrimer. Biomaterials 30, 6976-6985.

[25] Huang RQ, Qu YH, Ke WL, Zhu JH, Pei YY, Jiang C (2007) Efficient gene delivery targeted to the brain using a transferrin-conjugated polyethyleneglycol-modified polyamidoamine dendrimer. FASEB $J \mathbf{2 1}, 1117-1125$.

[26] Lockman PR, Oyewumi MO, Koziara JM, Roder KE, Mumper RJ, Allen DD (2003) Brain uptake of thiaminecoated nanoparticles. J Control Release 93, 271-282.

[27] Aktas Y, Yemisci M, Andrieux K, Gursoy RN, Alonso MJ, Fernandez-Megia E, Novoa-Carballal R, Quinoa E, Riguera R, Sargon MF, Celik HH, Demir AS, Hincal AA, Dalkara T, Capan Y, Couvreur P (2005) Development and brain delivery of chitosan-PEG nanoparticles functionalized with the monoclonal antibody OX26. Bioconjug Chem 16, 15031511.

[28] Brigger I, Morizet J, Aubert G, Chacun H, TerrierLacombe MJ, Couvreur P, Vassal G (2002) Poly(ethylene glycol)-coated hexadecylcyanoacrylate nanospheres display a combined effect for brain tumor targeting. J Pharmacol Exp Ther 303, 928-936.

[29] Kreuter J (2001) Nanoparticulate systems for brain delivery of drugs. Adv Drug Deliv Rev 47, 65-81.

[30] Lee HJ, Engelhardt B, Lesley J, Bickel U, Pardridge WM (2000) Targeting rat anti-mouse transferrin receptor monoclonal antibodies through blood-brain barrier in mouse. $J$ Pharmacol Exp Ther 292, 1048-1052.

[31] Dhanikula RS, Argaw A, Bouchard JF, Hildgen P (2008) Methotrexate loaded polyether-copolyester dendrimers for the treatment of gliomas: Enhanced efficacy and intratumoral transport capability. Mol Pharm 5, 105-116.

[32] Lafon M (2005) Rabies virus receptors. J Neurovirol 11, 82-87.

[33] Dou H, Morehead J, Destache CJ, Kingsley JD, Shlyakhtenko L, Zhou Y, Chaubal M, Werling J, Kipp J, Rabinow BE, Gendelman HE (2007) Laboratory investigations for the morphologic, pharmacokinetic, and anti-retroviral properties of indinavir nanoparticles in human monocyte-derived macrophages. Virology 358, 148-158.

[34] Suk JS, Suh J, Lai SK, Hanes J (2007) Quantifying the intracellular transport of viral and nonviral gene vectors in primary neurons. Exp Biol Med (Maywood) 232, 461-469.

[35] Rejman J, Oberle V, Zuhorn IS, Hoekstra D (2004) Sizedependent internalization of particles via the pathways of clathrin- and caveolae-mediated endocytosis. Biochem $J$ 377, 159-169.

[36] Lakadamyali M, Rust MJ, Zhuang X (2006) Ligands for clathrin-mediated endocytosis are differentially sorted into distinct populations of early endosomes. Cell 124, 9971009.

[37] Boussif O, Lezoualc'h F, Zanta MA, Mergny MD, Scherman D, Demeneix B, Behr JP (1995) A versatile vector for gene and oligonucleotide transfer into cells in culture and in vivo: Polyethylenimine. Proc Natl Acad Sci U S A 92, 7297-7301.

[38] Ohki EC, Tilkins ML, Ciccarone VC, Price PJ (2001) Improving the transfection efficiency of post-mitotic neurons. J Neurosci Methods 112, 95-99.

[39] Pérez-Carrión MD, Pérez-Martínez FC, Merino S, SánchezVerdú P, Martínez-Hernández J, Luján R, Ceña V (2012) Dendrimer-mediated siRNA delivery knocks down Beclin 1 and potentiates NMDA-mediated toxicity in rat cortical neurons. J Neurochem 120, 259-268. 
[40] Neu M, Fischer D, Kissel T (2005) Recent advances in rational gene transfer vector design based on poly(ethylene imine) and its derivatives. J Gene Med 7, 992-1009.

[41] Kleemann E, Neu M, Jekel N, Fink L, Schmehl T, Gessler T, Seeger W, Kissel T (2005) Nano-carriers for DNA delivery to the lung based upon a TAT-derived peptide covalently coupled to PEG-PEI. J Control Release 109, 299-316.

[42] Sethuraman VA, Bae YH (2007) TAT peptide-based micelle system for potential active targeting of anti-cancer agents to acidic solid tumors. J Control Release 118, 216-224.

[43] Torchilin VP (2006) Recent approaches to intracellular delivery of drugs and DNA and organelle targeting. Annu Rev Biomed Eng 8, 343-375.

[44] Harush-Frenkel O, Debotton N, Benita S, Altschuler Y (2007) Targeting of nanoparticles to the clathrin-mediated endocytic pathway. Biochem Biophys Res Commun 353 26-32.

[45] Gillies ER, Goodwin AP, Frechet JM (2004) Acetals as pHsensitive linkages for drug delivery. Bioconjug Chem $\mathbf{1 5}$ 1254-1263.

[46] Ropert C, Malvy C, Couvreur P (1993) Inhibition of the Friend retrovirus by antisense oligonucleotides encapsulated in liposomes: Mechanism of action. Pharm Res 10, 1427-1433.

[47] Roy I, Mitra S, Maitra A, Mozumdar S (2003) Calcium phosphate nanoparticles as novel non-viral vectors for targeted gene delivery. Int J Pharm 250, 25-33.

[48] Armatas GS, Kanatzidis MG (2006) Mesostructured germanium with cubic pore symmetry. Nature 441, 1122-1125.

[49] Trikalitis PN, Rangan KK, Bakas T, Kanatzidis MG (2001) Varied pore organization in mesostructured semiconductors based on the [SnSe4](4-) anion. Nature 410, 671-675.

[50] Zou X, Conradsson T, Klingstedt M, Dadachov MS, O'Keeffe M (2005) A mesoporous germanium oxide with crystalline pore walls and its chiral derivative. Nature $\mathbf{4 3 7}$ 716-719.

[51] Areva S, Aaritalo V, Tuusa S, Jokinen M, Linden M, Peltola $\mathrm{T}$ (2007) Sol-Gel-derived TiO2-SiO2 implant coatings for direct tissue attachment. Part II: Evaluation of cell response. J Mater Sci Mater Med 18, 1633-1642.

[52] Lai CY, Trewyn BG, Jeftinija DM, Jeftinija K, Xu S, Jeftinija S, Lin VS (2003) A mesoporous silica nanosphere-based carrier system with chemically removable CdS nanoparticle caps for stimuli-responsive controlled release of neurotransmitters and drug molecules. J Am Chem Soc $\mathbf{1 2 5}$, 4451-4459.

[53] Zhu MQ, Han JJ, Li AD (2007) CdSe/CdS/SiO2 core/shell/shell nanoparticles. J Nanosci Nanotechnol 7, 432-439.

[54] Dormer K, Seeney C, Lewelling K, Lian G, Gibson D, Johnson M (2005) Epithelial internalization of superparamagnetic nanoparticles and response to external magnetic field. Biomaterials 26, 2061-2072.

[55] Corso TD, Torres G, Goulah C, Roy I, Gambino AS, Nayda J, Buckley T, Stachowiak EK, Bergey EJ, Pudavar H, Dutta P, Bloom DC, Bowers WJ, Stachowiak MK (2005) Assessment of viral and non-viral gene transfer into adult rat brains using HSV-1, calcium phosphate and PEI-based methods. Folia Morphol (Warsz) 64, 130-144.

[56] Slowing II, Vivero-Escoto JL, Wu CW, Lin VS (2008) Mesoporous silica nanoparticles as controlled release drug delivery and gene transfection carriers. Adv Drug Deliv Rev 60, 1278-1288.

[57] Jeffery ND, McBain SC, Dobson J, Chari DM (2009) Uptake of systemically administered magnetic nanoparticles
(MNPs) in areas of experimental spinal cord injury (SCI). $J$ Tissue Eng Regen Med 3, 153-157.

[58] Estevanato L, Cintra D, Baldini N, Portilho F, Barbosa L, Martins O, Lacava B, Miranda-Vilela AL, Tedesco AC, Bao S, Morais PC, Lacava ZG (2011) Preliminary biocompatibility investigation of magnetic albumin nanosphere designed as a potential versatile drug delivery system. Int $J$ Nanomedicine 6, 1709-1717.

[59] Wong HL, Chattopadhyay N, Wu XY, Bendayan R (2010) Nanotechnology applications for improved delivery of antiretroviral drugs to the brain. Adv Drug Deliver Rev 62, 503-517.

[60] Lai WF, Lin MC (2009) Nucleic acid delivery with chitosan and its derivatives. J Control Release 134, 158-168.

[61] Kim TH, Jiang HL, Nah JW, Cho MH, Akaike T, Cho CS (2007) Receptor-mediated gene delivery using chemically modified chitosan. Biomed Mater 2, S95-S100.

[62] Sano A, Maeda M, Nagahara S, Ochiya T, Honma K, Itoh H, Miyata T, Fujioka K (2003) Atelocollagen for protein and gene delivery. Adv Drug Deliv Rev 55, 1651-1677.

[63] Felgner PL, Gadek TR, Holm M, Roman R, Chan HW, Wenz M, Northrop JP, Ringold GM, Danielsen M (1987) Lipofection: A highly efficient, lipid-mediated DNA-transfection procedure. Proc Natl Acad Sci U S A 84, 7413-7417.

[64] Behr JP, Demeneix B, Loeffler JP, Pérez-Mutul J (1989) Efficient gene transfer into mammalian primary endocrine cells with lipopolyamine-coated DNA. Proc Natl Acad Sci U S A 86, 6982-6986.

[65] Guerra-Crespo M, Charli JL, Rosales-García VH, PedrazaAlva G, Pérez-Martínez L (2003) Polyethylenimine improves the transfection efficiency of primary cultures of post-mitotic rat fetal hypothalamic neurons. J Neurosci Methods 127, 179-192.

[66] Ryman BE, Jewkes RF, Jeyasingh K, Osborne MP, Patel HM, Richardson VJ, Tattersall MH, Tyrrell DA (1978) Potential applications of liposomes to therapy. Ann N Y Acad Sci 308, 281-307.

[67] Bangham AD (1995) Surrogate cells or Trojan horses. The discovery of liposomes. Bioessays 17, 1081-1088.

[68] Schnyder A, Huwyler J (2005) Drug transport to brain with targeted liposomes. NeuroRx 2, 99-107.

[69] Torchilin VP (2008) Tat peptide-mediated intracellular delivery of pharmaceutical nanocarriers. Adv Drug Deliv Rev 60, 548-558.

[70] Cardoso AL, Costa P, de Almeida LP, Simoes S, Plesnila N, Culmsee C, Wagner E, Pedroso de Lima MC (2009) Tf-lipoplex-mediated c-Jun silencing improves neuronal survival following excitotoxic damage in vivo. J Control Release 109, 392-403.

[71] Lockman PR, Oyewumi MO, Koziara JM, Roder KE, Mumper RJ, Allen DD (2003) Brain uptake of thiaminecoated nanoparticles. J Control Release 93, 271-282.

[72] Holt CE, Garlick N, Cornel E (1990) Lipofection of cDNAs in the embryonic vertebrate central nervous system. Neuron 4, 203-214.

[73] Imaoka T, Date I, Ohmoto T, Nagatsu T (1998) Significant behavioral recovery in Parkinson's disease model by direct intracerebral gene transfer using continuous injection of a plasmid DNA-liposome complex. Hum Gene Ther 9, 10931102.

[74] Zhang Y, Schlachetzki F, Zhang YF, Boado RJ, Pardridge WM (2004) Normalization of striatal tyrosine hydroxylase and reversal of motor impairment in experimental parkinsonism with intravenous nonviral gene therapy and a brain-specific promoter. Hum Gene Ther 15, 339-350. 
[75] Zou LL, Huang L, Hayes RL, Black C, Qiu YH, Perez-Polo JR, Le W, Clifton GL, Yang K (1999) Liposomemediated NGF gene transfection following neuronal injury: Potential therapeutic applications. Gene Ther 6, 9941005.

[76] da Cruz MT, Cardoso AL, de Almeida LP, Simoes S, de Lima MC (2005) Tf-lipoplex-mediated NGF gene transfer to the CNS: Neuronal protection and recovery in an excitotoxic model of brain injury. Gene Ther 12, 1242-1252.

[77] Zhang Y, Jeong LH, Boado RJ, Pardridge WM (2002) Receptor-mediated delivery of an antisense gene to human brain cancer cells. J Gene Med 4, 183-194.

[78] Zhang Y, Zhang YF, Bryant J, Charles A, Boado RJ, Pardridge WM (2004) Intravenous RNA interference gene therapy targeting the human epidermal growth factor receptor prolongs survival in intracranial brain cancer. Clin Cancer Res 10, 3667-3677.

[79] Boado RJ (2005) RNA interference and nonviral targeted gene therapy of experimental brain cancer. NeuroRx 2, 139150.

[80] Wissing SA, Kayser O, Muller RH (2004) Solid lipid nanoparticles for parenteral drug delivery. Adv Drug Deliv Rev 56, 1257-1272.

[81] Harivardhan Reddy L, Sharma RK, Chuttani K, Mishra AK, Murthy RS (2005) Influence of administration route on tumor uptake and biodistribution of etoposide loaded solid lipid nanoparticles in Dalton's lymphoma tumor bearing mice. J Control Release 105, 185-198.

[82] Manjunath K, Venkateswarlu V (2005) Pharmacokinetics, tissue distribution and bioavailability of clozapine solid lipid nanoparticles after intravenous and intraduodenal administration. J Control Release 107, 215-228.

[83] Mehnert W, Mader K (2001) Solid lipid nanoparticles: Production, characterization and applications. Adv Drug Deliv Rev 47, 165-196.

[84] Troster SD, Kreuter J (1992) Influence of the surface properties of low contact angle surfactants on the body distribution of 14C-poly(methyl methacrylate) nanoparticles. J Microencapsul 9, 19-28.

[85] Scholer N, Olbrich C, Tabatt K, Muller RH, Hahn H, Liesenfeld O (2001) Surfactant, but not the size of solid lipid nanoparticles (SLN) influences viability and cytokine production of macrophages. Int J Pharm 221, 57-67.

[86] Peira E, Marzola P, Podio V, Aime S, Sbarbati A, Gasco MR (2003) In vitro and in vivo study of solid lipid nanoparticles loaded with superparamagnetic iron oxide. J Drug Target 11, 19-24.

[87] Koziara JM, Lockman PR, Allen DD, Mumper RJ (2004) Paclitaxel nanoparticles for the potential treatment of brain tumors. J Control Release 99, 19-24.

[88] Abdallah B, Hassan A, Benoist C, Goula D, Behr JP, Demeneix BA (1996) A powerful nonviral vector for in vivo gene transfer into the adult mammalian brain: Polyethylenimine. Hum Gene Ther 7, 1947-1954.

[89] Alyaudtin RN, Reichel A, Lobenberg R, Ramge P, Kreuter J, Begley DJ (2001) Interaction of poly(butylcyanoacrylate) nanoparticles with the blood-brain barrier in vivo and in vitro. J Drug Target 9, 209-221.

[90] Gao K, Jiang X (2006) Influence of particle size on transport of methotrexate across blood brain barrier by polysorbate 80 -coated polybutylcyanoacrylate nanoparticles. Int J Pharm 310, 213-219.

[91] Dechy-Cabaret O, Martin-Vaca B, Bourissou D (2004) Controlled ring-opening polymerization of lactide and glycolide. Chem Rev 104, 6147-6176.
[92] Leonard DJ, Pick LT, Farrar DF, Dickson GR, Orr JF, Buchanan FJ (2009) The modification of PLA and PLGA using electron-beam radiation. J Biomed Mater Res A 89 567-574.

[93] Dunlap DD, Maggi A, Soria MR, Monaco L (1997) Nanoscopic structure of DNA condensed for gene delivery. Nucleic Acids Res 25, 3095-3101.

[94] Demeneix B, Hassani Z, Behr JP (2004) Towards multifunctional synthetic vectors. Curr Gene Ther 4, 445-455.

[95] Godbey WT, Wu KK, Mikos AG (1999) Poly(ethylenimine) and its role in gene delivery. $J$ Control Release 60, 149-160.

[96] Helander IM, Alakomi HL, Latva-Kala K, Koski P (1997) Polyethyleneimine is an effective permeabilizer of gramnegative bacteria. Microbiology 143, 3193-3199.

[97] Kim JM, Lee M, Kim KH, Ha Y, Choi JK, Park SR, Park H, Park HC, Ahn CH, Kim SW, Choi BH (2009) Gene therapy of neural cell injuries in vitro using the hypoxiainducible GM-CSF expression plasmids and water-soluble lipopolymer (WSLP). J Control Release 133, 60-67.

[98] Ogris M, Brunner S, Schuller S, Kircheis R, Wagner E (1999) PEGylated DNA/transferrin-PEI complexes: Reduced interaction with blood components, extended circulation in blood and potential for systemic gene delivery. Gene Ther 6, 595-605.

[99] Park IK, Lasiene J, Chou SH, Horner PJ, Pun SH (2007) Neuron-specific delivery of nucleic acids mediated by Tet1modified poly(ethylenimine). J Gene Med 9, 691-702.

[100] Andreu A, Fairweather N, Miller AD (2008) Clostridium neurotoxin fragments as potential targeting moieties for liposomal gene delivery to the CNS. Chembiochem 9, 219231

[101] Bergen JM, Park IK, Horner PJ, Pun SH (2008) Nonviral approaches for neuronal delivery of nucleic acids. Pharm Res 25, 983-998.

[102] Bazile D, Prud'homme C, Bassoullet MT, Marlard M, Spenlehauer G, Veillard M (1995) Stealth Me. PEG-PLA nanoparticles avoid uptake by the mononuclear phagocytes system. J Pharm Sci 84, 493-498.

[103] Peracchia MT, Vauthier C, Desmaele D, Gulik A, Dedieu JC, Demoy M, D'Angelo J, Couvreur P (1998) Pegylated nanoparticles from a novel methoxypolyethylene glycol cyanoacrylate-hexadecyl cyanoacrylate amphiphilic copolymer. Pharm Res 15, 550-556.

[104] Calvo P, Gouritin B, Villarroya H, Eclancher F, Giannavola C, Klein C, Andreux JP, Couvreur P (2002) Quantification and localization of PEGylated polycyanoacrylate nanoparticles in brain and spinal cord during experimental allergic encephalomyelitis in the rat. Eur J Neurosci 15, 1317-1326.

[105] Araujo L, Lobenberg R, Kreuter J (1999) Influence of the surfactant concentration on the body distribution of nanoparticles. J Drug Target 6, 373-385.

[106] Blasi P, Giovagnoli S, Schoubben A, Ricci M, Rossi C (2007) Solid lipid nanoparticles for targeted brain drug delivery. Adv Drug Deliv Rev 59, 454-477.

[107] Bandyopadhyay P, Ma X, Linehan-Stieers C, Kren BT, Steer CJ (1999) Nucleotide exchange in genomic DNA of rat hepatocytes using RNA/DNA oligonucleotides. Targeted delivery of liposomes and polyethyleneimine to the asialoglycoprotein receptor. J Biol Chem 274, 10163-10172.

[108] Iwai M, Harada Y, Tanaka S, Muramatsu A, Mori T, Kashima K, Imanishi J, Mazda O (2002) Polyethylenimine-mediated suicide gene transfer induces a therapeutic effect for hepatocellular carcinoma in vivo by using an Epstein-Barr virus-based plasmid vector. Biochem Biophys Res Commun 291, 48-54. 
[109] Aigner A, Fischer D, Merdan T, Brus C, Kissel T, Czubayko F (2002) Delivery of unmodified bioactive ribozymes by an RNA-stabilizing polyethylenimine (LMW-PEI) efficiently down-regulates gene expression. Gene Ther 9, 1700-1707.

[110] Lemkine GF, Goula D, Becker N, Paleari L, Levi G, Demeneix BA (1999) Optimisation of polyethyleniminebased gene delivery to mouse brain. J Drug Target 7, 305-312.

[111] Goula D, Remy JS, Erbacher P, Wasowicz M, Levi G, Abdallah B, Demeneix BA (1998) Size, diffusibility and transfection performance of linear PEI/DNA complexes in the mouse central nervous system. Gene Ther 5, 712717.

[112] Shi L, Tang GP, Gao SJ, Ma YX, Liu BH, Li Y, Zeng JM, Ng YK, Leong KW, Wang S (2003) Repeated intrathecal administration of plasmid DNA complexed with polyethylene glycol-grafted polyethylenimine led to prolonged transgene expression in the spinal cord. Gene Ther 10, 11791188 .

[113] Tang GP, Guo HY, Alexis F, Wang X, Zeng S, Lim TM, Ding J, Yang YY, Wang S (2006) Low molecular weight polyethylenimines linked by beta-cyclodextrin for gene transfer into the nervous system. J Gene Med 8, 736-744.

[114] Azzouz M, Ralph GS, Storkebaum E, Walmsley LE, Mitrophanous KA, Kingsman SM, Carmeliet P, Mazarakis ND (2004) VEGF delivery with retrogradely transported lentivector prolongs survival in a mouse ALS model. Nature 429, 413-417

[115] Wang S, Ma N, Gao SJ, Yu H, Leong KW (2001) Transgene expression in the brain stem effected by intramuscular injection of polyethylenimine/DNA complexes. Mol Ther 3 , 658-664.

[116] Lee CC, MacKay JA, Frechet JM, Szoka FC (2005) Designing dendrimers for biological applications. Nat Biotechnol 23, $1517-1526$

[117] Tang MX, Redemann CT, Szoka FC Jr (1996) In vitro gene delivery by degraded polyamidoamine dendrimers. Bioconjug Chem 7, 703-714.

[118] Choi YS, Cho TS, Kim JM, Han SW, Kim SK (2006) Amine terminated G-6 PAMAM dendrimer and its interaction with DNA probed by Hoechst 33258. Biophys Chem 121, 142149.

[119] Abe H, Keen KL, Terasawa E (2008) Rapid action of estrogens on intracellular calcium oscillations in primate luteinizing hormone-releasing hormone-1 neurons. Endocrinology 149, 1155-1162.

[120] An Y, Jiang X, Bi W, Chen H, Jin L, Zhang S, Wang C, Zhang W (2012) Sensitive electrochemical immunosensor for alpha-synuclein based on dual signal amplification using PAMAM dendrimer-encapsulated $\mathrm{Au}$ and enhanced gold nanoparticle labels. Biosens Bioelectron 32, 224230.

[121] Posadas I, López-Hernández B, Clemente MI, Jiménez JL, Ortega P, de la MJ, Gómez R, Muñoz-Fernández MA, Ceña V (2009) Highly efficient transfection of rat cortical neurons using carbosilane dendrimers unveils a neuroprotective role for HIF-1alpha in early chemical hypoxia-mediated neurotoxicity. Pharm Res 26, 1181-1191.

[122] Kim JB, Choi JS, Nam K, Lee M, Park JS, Lee JK (2006) Enhanced transfection of primary cortical cultures using arginine-grafted PAMAM dendrimer, PAMAM-Arg. J Control Release 114, 110-117.

[123] Kim TI, Bai CZ, Nam K, Park JS (2009) Comparison between arginine conjugated PAMAM dendrimers with structural diversity for gene delivery systems. J Control Release 136, 132-139.

[124] Rodrigo AC, Rivilla I, Pérez-Martínez FC, Monteagudo S, Ocaña V, Guerra J, García-Martínez JC, Merino S, Sánchez-Verdú P, Ceña V, Rodríguez-López J (2011) Efficient, Non-Toxic Hybrid PPV-PAMAM Dendrimer as a Gene Carrier for Neuronal Cells. Biomacromolecules 12, 1205-1213.

[125] Posadas I, Pérez-Martínez FC, Guerra J, Sánchez-Verdú P, Ceña V (2012) Cofilin activation mediates Bax translocation to mitochondria during excitotoxic neuronal death. $J$ Neurochem 120, 515-527.

[126] Agrawal A, Min DH, Singh N, Zhu H, Birjiniuk A, von MG, Harris TJ, Xing D, Woolfenden SD, Sharp PA, Charest A, Bhatia S (2009) Functional delivery of siRNA in mice using dendriworms. ACS Nano 3, 2495-2504.

[127] Mishra V, Mahor S, Rawat A, Gupta PN, Dubey P, Khatri K, Vyas SP (2006) Targeted brain delivery of AZT via transferrin anchored pegylated albumin nanoparticles. J Drug Target 14, 45-53.

[128] Demeule M, Currie JC, Bertrand Y, Che C, Nguyen T, Regina A, Gabathuler R, Castaigne JP, Beliveau R (2008) Involvement of the low-density lipoprotein receptor-related protein in the transcytosis of the brain delivery vector angiopep-2. J Neurochem 106, 1534-1544.

[129] Huang R, Ke W, Liu Y, Jiang C, Pei Y (2008) The use of lactoferrin as a ligand for targeting the polyamidoaminebased gene delivery system to the brain. Biomaterials $\mathbf{2 9}$, 238-246.

[130] Kim ID, Lim CM, Kim JB, Nam HY, Nam K, Kim SW, Park JS, Lee JK (2010) Neuroprotection by biodegradable PAMAM ester (e-PAM-R)-mediated HMGB1 siRNA delivery in primary cortical cultures and in the postischemic brain. J Control Release 142, 422-430.

[131] Arribas AS, Moreno M, Bermejo E, Angeles Lorenzo M, Zapardiel A, Chicharro M (2009) Design and adaptation of miniaturized electrochemical devices integrating carbon nanotube-based sensors to commercial CE equipment. Electrophoresis 30, 3480-3488.

[132] Keefer EW, Botterman BR, Romero MI, Rossi AF, Gross GW (2008) Carbon nanotube coating improves neuronal recordings. Nat Nanotechnol 3, 434-439.

[133] Pantarotto D, Briand JP, Prato M, Bianco A (2004) Translocation of bioactive peptides across cell membranes by carbon nanotubes. Chem Commun (Camb), 16-17.

[134] Kostarelos K, Bianco A, Prato M (2009) Promises, facts and challenges for carbon nanotubes in imaging and therapeutics. Nat Nanotechnol 4, 627-633.

[135] Lovat V, Pantarotto D, Lagostena L, Cacciari B, Grandolfo M, Righi M, Spalluto G, Prato M, Ballerini L (2005) Carbon nanotube substrates boost neuronal electrical signaling. Nano Lett 5, 1107-1110.

[136] Cellot G, Cilia E, Cipollone S, Rancic V, Sucapane A, Giordani S, Gambazzi L, Markram H, Grandolfo M, Scaini D, Gelain F, Casalis L, Prato M, Giugliano M, Ballerini L (2009) Carbon nanotubes might improve neuronal performance by favouring electrical shortcuts. Nat Nanotechnol 4, 126-133.

[137] Malarkey EB, Fisher KA, Bekyarova E, Liu W, Haddon RC, Parpura V (2009) Conductive single-walled carbon nanotube substrates modulate neuronal growth. Nano Lett $\mathbf{9}$, 264-268.

[138] Donaldson K, Tran CL (2004) An introduction to the shortterm toxicology of respirable industrial fibres. Mutat Res 553, 5-9. 
[139] Iijima S, Yudasaka M, Yamada R, Bandow S, Suenaga K, Kokai F, Takahashi K (1999) Nano-aggregates of singlewalled graphitic carbon nano-horns. Chem Phys Lett 309, 165-170.

[140] Ajima K, Yudasaka M, Murakami T, Maigne A, Shiba K, Iijima S (2005) Carbon nanohorns as anticancer drug carriers. Mol Pharm 2, 475-480.
[141] Miyawaki J, Matsumura S, Yuge R, Murakami T, Sato $\mathrm{S}$, Tomida A, Tsuruo T, Ichihashi T, Fujinami T, Irie H, Tsuchida K, Iijima S, Shiba K, Yudasaka M (2009) Biodistribution and ultrastructural localization of singlewalled carbon nanohorns determined in vivo with embedded Gd2O3 labels. ACS Nano 3, 1399-1406. 